\title{
Civil Discovery of Documents Held by a Grand Jury
}

Advocates of the doctrine of grand jury secrecy have pronounced it "indispensable," 1 and those who would limit its application have termed it "antiquated." to provide a clear definition of its boundaries. For example, although it is settled that civil litigants may not obtain through discovery transcripts of live testimony absent a showing of "particularized need,"3 the courts are divided over whether documents that have been subpoenaed by a grand jury as evidence should be subjected to the same strict standard of necessity. ${ }^{4}$

Central to the dispute is the proper interpretation of rule 6(e) of the Federal Rules of Criminal Procedure. ${ }^{5}$ That rule prohibits

3 United States v. Johnson, 319 U.S. 503, 513 (1943). Accord, Douglas Oil Co. v. Petrol Stops Northwest, 441 U.S. 211, 218 (1979) ("We consistently have recognized that the proper functioning of our grand jury system depends upon the secrecy of grand jury proceedings").

2 Dash, The Indicting Grand Jury: A Critical Stage?, 10 Am. Crm. L. Rev. 807, 818 (1972). See also Sherry, Grand Jury Minutes: The Unreasonable Rule of Secrecy, 48 VA. L. REv. 668, 684 (1962).

${ }^{3}$ E.g., Pittsburgh Plate Glass Co. v. United States, 360 U.S. 395, 400 (1959); United States v. Procter \& Gamble Co., 356 U.S. 677, 682 (1958) (the need must be particularized and compelling). Accord, Douglas Oil Co. v. Petrol Stops Northwest, 441 U.S. 211, 218 (1979). See generally 1 C. Wright, Federal Practice and Procedure § 109 (1969).

- Compare United States v. Stanford, 589 F.2d 285, 291 (7th Cir. 1978), cert. denied, 440 U.S. 983 (1979); Illinois v. Sarbaugh, 552 F.2d 768, 772 n.2 (7th Cir.), cert. denied, 434 U.S. 889 (1977); United States v. Interstate Dress Carriers, Inc., 280 F.2d 52 (2d Cir. 1960); In re Grand Jury Investigation of Ven-Fuel, 441 F. Supp. 1299, 1303-04 (M.D. Fla. 1977); United States v. Saks \& Co., 426 F. Supp. 812, 814-15 (S.D.N.Y. 1976); Capital Indem. Corp. v. First Minn. Constr. Co., 405 F. Supp. 929, 930-31 (D. Mass. 1975); Davis v. Romney, 55 F.R.D. 337, 341-42 (E.D. Pa. 1972); In re Hearings Before the Comm. on Banking \& Currency, 19 F.R.D. 410 (N.D. Ill. 1956); and Michelin Tire Corp. v. United States, 453 F. Supp. 897 (Cust. Ct. 1978) with In re Grand Jury Proceedings, 309 F.2d 440 (3d Cir. 1962); Cain v. United States, 239 F.2d 263 (7th Cir. 1956); In re Grand Jury, 469 F. Supp. 666, 669 (M.D. Pa. 1978); Corona Constr. Co. v. Ampress Brick Co., 376 F. Supp. 598 (N.D. Ill. 1974); In re California, 195 F. Supp. 37, 40-41 (E.D. Pa. 1961); and United States v. Stein, 18 F.R.D. 17, 19 (S.D.N.Y. 1955), rev'd on other grounds sub nom. United States v. Jackson, 257 F.2d 830 (2d Cir. 1958).

- FED. R. CRIM. P. 6(e). Rule 6(e)(2) provides in part:

A grand juror, an interpreter, a stenographer, an operator of a recording device, a typist who transcribes recorded testimony, an attorney for the government, or [an assistant to a government attorney] shall not disclose matters occurring before the grand 
anyone attending grand jury proceedings, ${ }^{8}$ with the exception of the witnesses, from "disclos[ing] matters occurring before the grand jury" without a court order. ${ }^{7}$ What constitutes disclosure of "matters occurring before the grand jury," particularly in the context of subpoenaed documents, remains unclear.

Whether a particular document subpoenaed by the grand jury is within the scope of rule 6(e) will frequently determine whether it can be obtained by a civil plaintiff or a government agency engaged in civil or regulatory matters. If documents are subject, under all circumstances, to rule 6(e), and the grand jury holds the only available copy of the document, it will not be discoverable unless there is proof of a particularized need..$^{8}$ Furthermore, the document will

jury, except as otherwise provided for in these rules.

FED. R. CRIM. P. 6(e)(3)(C) provides in part:

Disclosure otherwise prohibited by this rule of matters occurring before the grand jury may . . . be made-

(i) when so directed by a court preliminarily to or in connection with a judicial proceeding ....

....

If the court orders disclosure of matters occurring before the grand jury, the disclosure shall be made in such manner, at such time, and under such conditions as the court may direct.

The list of persons subject to rule 6(e)(2) is exclusive. It corresponds to the list of persons entitled to be present at grand jury proceedings under rule 6(d), see note 6 infra, except that it includes government attorney's assistants, and does not include witnesses under examination before the grand jury.

Rule $6(e)(3)(C)$ (ii) authorizes disclosure to a criminal defendant of matters occurring before the grand jury that may provide grounds for dismissing an indictment. See generally $1 \mathrm{C}$. WRIGHT, supra note $3, \S 108$.

Rule $6(\mathrm{e})(3)(\mathrm{A})(\mathrm{i})$ authorizes disclosure of information to government attorneys for use in performance of their duties. Rule 6(e)(3)(A)(ii), added in 1977, likewise permits disclosure to other government personnel whose assistance is required by federal prosecutors. This authority was added to enable prosecutors to use the services of federal agents and other nonattorney experts. FED. R. CRIM. P. 6, Notes of Advisory Comm. on 1977 Amendments to Rules; S. ReP. No. 354, 95th Cong., 1st Sess. 6 (1977).

For a general treatment of rule 6(e), see 4 J. Moore, Federal Practice II 26.61[6.-3] (2d ed. 1979); 8 id. I 6.05; 1 C. WRIGHT, supra note 3, $\$$ 106-109; Orfield, The Federal Grand Jury, 22 F.R.D. 343 (1959).

- FED. R. CRIM. P. 6(d), which governs who shall be permitted to be present in the grand jury room, provides:

Attorneys for the government, the witness under examination, interpreters when needed and, for the purpose of taking the evidence, a stenographer or operator of a recording device may be present while the grand jury is in session, but no person other than the jurors may be present while the grand jury is deliberating or voting.

7 Fen. R. CRIM. P. 6(e)(2).

- In addition to proof of particularized need, government agencies have to show that the documents are required in connection with a judicial proceeding as required by rule $6(e)-a$ showing that is not necessary when the agency has subpoena power and there is no grand jury. 
remain undiscoverable until it is eventually released to its original owners-an event that may take years. ${ }^{9}$ Yet if a civil plaintiff can easily obtain the documents amassed by a grand jury, he will be able to make use of the investigative powers of the grand jury to prepare his private suit. He may even be able to obtain documents he would not have been able to discover had there been no grand jury proceeding.

This comment considers whether the discovery of documents held by a grand jury constitutes disclosure of "matters occurring before the grand jury," and is, therefore, within the scope of rule 6(e). Neither the words of the statute nor its legislative history compel any single resolution of this issue. The courts also have failed to advance any unified or principled approach. Analysis of the reasons for grand jury secrecy indicates that rule 6(e) should be interpreted as prohibiting any disclosure that reveals the scope, progress, or results of grand jury proceedings. Such a reading of the rule would bar the direct release of any document from a grand jury to someone other than its original owner. This comment proposes that document requests be channeled through the original owner, a procedural innovation which will ensure that rule 6(e) does not interfere with the discovery of documents in civil litigation.

\section{Rule 6(e)}

Rule 6(e) of the Federal Rules of Criminal Procedure prohibits those attending grand jury proceedings, other than witnesses, from "disclos[ing] matters occurring before the grand jury" without a court order. ${ }^{10}$ The Supreme Court repeatedly has held that a court may order such a disclosure only when there has been a showing of

This comment considers only the situation in which the sole copy of the document is in the possession of the grand jury. Whether the owner must disclose documents of which the grand jury has another copy has received little attention from the courts.

- Documents subpoenaed by a grand jury should be returned to their owner after the grand jury has examined them. John Rosenblum, Inc. v. Gillespie, 187 F. Supp. 258 (S.D.N.Y. 1960); In re Bendix Aviation Corp., 58 F. Supp. 953 (S.D.N.Y. 1945). The grand jury may pursue a single investigation for a long time, however, especially in complex matters such as antitrust conspiracies or corruption cases (where large-scale subpoenaing of documents is perhaps most common). The standard term of a grand jury is eighteen months, but it may be extended up to a maximum of thirty-six months if "the business of the grand jury has not been completed," 18 U.S.C. $\S 3331$ (a) (1976), or even longer for investigations of official misconduct or organized crime, $i d$. $\S 3333(\mathrm{e})$. Even at the dissolution of the grand jury, the documents may be turned over to the Justice Department for use in prosecution.

${ }_{10}$ See note 5 supra. 
particularized need for it in connection with judicial proceedings. ${ }^{11}$ That need must be sufficient to outweigh the countervailing policy of grand jury secrecy. ${ }^{12}$

Rule 6(e) thus establishes a substantial barrier to disclosure of "matters occurring before the grand jury":13 a showing of particularized need. The meaning of that phrase-"disclos[ure] of matters occurring before the grand jury"-is therefore of critical importance. As several courts have noted, the word "matters" is extremely broad in scope; ${ }^{14}$ it is difficult to isolate any items that could not be included within "matters." In using such a word, the rule's authors could not have intended to describe only transcripts or any other narrow, formal category.

On the other hand, the authors could have used a broader formulation than the one they chose, such as "information before the grand jury," or "grand jury matters." The phrase "occurring before the grand jury" arguably suggests a limitation;16 only events in time "occur." Documents, unlike actual testimony, do not occur before a grand jury; rather, they are subpoenaed by it, presented to it, or examined by it. Reading the phrase narrowly would thus serve to protect only events taking place inside the jury room. Thus, it might not protect the identity of grand jury witnesses-something that has always been held protected by the doctrine of grand jury secrecy. ${ }^{16}$

One way out of this dilemma is to focus, not on the phrase "matters occurring before the grand jury," but on the preceding word "disclose."17 "Disclosure" need not be limited to a literal transfer of a document or a verbatim report of a statement. Instead, disclosure might comprehend any statement or act that reveals a fact not otherwise known to the hearer. Rule 6(e) would

11 See cases cited note 3 supra.

12 See cases cited note 3 supra.

13 See, e.g., United States v. Edelson, 581 F.2d 1290, 1291-92 (7th Cir. 1978) (per curiam). See also $1 \mathrm{C}$. WRIGHT, supra note $3, \S 106$, at 172-74. Courts may be becoming more liberal in allowing exceptions to the secrecy requirement under rule 6(e). See id. Cf. Dennis v. United States, 384 U.S. 855 (1966) (abuse of discretion to deny transcripts of testimony to criminal defendant for use in impeaching witnesses).

14 See United States Indus., Inc. v. United States Dist. Court, 345 F.2d 18, 20-21 (9th Cir.), cert. denied, 382 U.S. 814 (1965); United States v. Armco Steel Corp., 458 F. Supp. 784, 789 (W.D. Mo. 1978).

${ }_{15}$ See Davis v. Romney, 55 F.R.D. 337, 341 (E.D. Pa. 1972); In re Hearings Before the Comm. on Banking \& Currency, 19 F.R.D. 410, 412-13 (N.D. Ill. 1956).

${ }_{16}$ See, e.g., Minnesota v. United States Steel Corp., 44 F.R.D. 559, 579-80 .(D. Minn. 1968); United States v. Elliot, 266 F. Supp. 318, 327 (S.D.N.Y. 1967).

17 See note 5 supra. 
then prohibit the release of information that would reveal the subject matter, scope, progress, or results of the grand jury's proceedings. Thus, although a list of witnesses is not, in itself, a "matter occurring before the grand jury," disclosure of the list would be prohibited by the rule because the disclosure would reveal information about the substance of the grand jury inquiry. Similarly, although a subpoenaed document does not "occur before" a grand jury, the knowledge that the document has been sought and obtained by the grand jury may be informative.

Although this construction of the rule is reasonable, it is not dictated by the language of the statute. Nothing in the history of the rule would require or prohibit it.

The general requirement that grand jury proceedings be kept secret was well established at common law long before the adoption of the Federal Rules of Criminal Procedure in 1946. ${ }^{18}$ In 1940, Congress authorized the Supreme Court to prescribe uniform rules of criminal procedure for the federal courts, subject to congressional review. ${ }^{19}$ The Court delegated the task of drafting the rules to an advisory committee. This committee drafted the Federal Rules of Criminal Procedure; the draft included rule 6(e), which codified the common-law rule of grand jury secrecy. Unfortunately, the legislative history of rule 6(e) does not indicate whether Congress envisioned the rule as comprehending documents held by a grand jury. The final rule was a product of numerous drafts of the proposed Federal Rules. ${ }^{20}$ None of the drafts, however, provides

${ }_{18}$ See Orfield, supra note 5, at 402-13. In 1940, the sole statutory provision respecting grand jury secrecy concerned disclosure of jurors' votes on particular indictments. See Act of Apr. 30, 1934, ch. 170, 2 , 48 Stat. 649 . The main provision of that section dealt with the validity of an indictment when jurors were unqualified. The section bars testimony by a juror with regard to any particular individual's vote, and provides that the foreman's vote tallies are not to be made public except by court order; by its terms the section does not forbid a juror to discuss jury voting off the witness stand.

19 See Act of June 29,1940 , ch. 445,54 Stat. 688 (current version at 18 U.S.C. $\S 3771$ (1976)).

${ }^{20}$ In the first two drafts of the Rules, the Committee made no provision whatever concerning the secrecy of grand juries. See Orfield, supra note 5, at 346. The third draft did contain a secrecy rule, but its provisions were limited to testimony about jurors' votes and disclosure of indictments prior to the arrest of the indictees. See id. at 346-47. The draft specified oaths for grand jurors, which may well have been intended as a secrecy requirement. Such oaths had been required in thirty-seven federal district courts. Id. at 403 . The first general secrecy rule appeared in the fourth draft, and provided that neither the testimony of witnesses nor anything said by a grand juror should be disclosed by a grand juror or witness. See id. at 347 . In the fifth draft, the prohibition was applied only to jurors. See id. at 348 . The sixth draft retained this provision and added a provision making it unlawful for any person to obstruct the grand jury, the court, or a federal officer by disclosing anything 
much help in ascertaining the scope of the phrase "matters occurring before the grand jury." The committee's notes address the issue of the rule's scope only in general terms: "This rule continues the traditional practice of secrecy on the party [sic] of members of the grand jury, except when the court permits a disclosure . . . ."21 Neither of the two cases cited as examples of the "traditional practice" considers whether documents are protected by the practice of grand jury secrecy. ${ }^{22}$ One court referred to "documents produced," but there is no indication whether the court considered document production appropriate. ${ }^{23}$ Indeed, prior to the adoption of rule 6(e), no court had ever addressed the question of what materials and events were protected by the practice of grand jury secrecy. $^{24}$

said or done during the proceedings. See id. at 348-49. The purpose of this provision was "to place some brake upon unrestricted disclosure without penalizing innocent and harmless disclosure." See id. at 349.

It was not until the "first preliminary draft" (the Committee's seventh draft) that the secrecy provision became substantively equivalent to the current rule. This version of the rule stated that a juror, attorney, interpreter, clerk, or stenographer may disclose matters occurring before the grand jury only by court order, either in connection with a judicial proceeding or upon a showing by the defendant that, because of matters occurring before the grand jury, grounds for dismissal exist. See id. at 349-50. Subsequent drafts provided for disclosure to government attorneys and added language indicating that rule 6(e) is the exclusive source of any secrecy obligation, but did not change the basic formulation. See id. at 354-55, 357.

Only recently has there been any evidence that Congress is even aware of the controversy concerning disclosure of documents. The situation was briefly mentioned in hearings conducted in 1976. Federal Grand Jury: Hearings on H.J. Res. 46, H.R. 1277 Before the Subcomm. on Immigration, Citizenship and International Law of the House Comm. on the Judiciary, 94th Cong., 2d Sess. 701 (1976) (prepared text by Charles Doyle, Legislative Attorney, American Law Division, Library of Congress).

${ }^{21}$ FEd. R. Crim. P. 6(e), Notes of Advisory Comm. on Rules. The Notes go on to discuss disclosure to government attorneys, inapplicability of the rule to witnesses, and sealing of indictments.

${ }^{22}$ See Schmidt v. United States, 115 F.2d 394 (6th Cir. 1940); United States v. American Medical Ass'n, 26 F. Supp. 429 (D.D.C. 1939).

${ }^{23}$ See Schmidt v. United States, 115 F.2d 394, 395 (quoting jury instructions). In Schmidt, two attorneys were prosecuted for contempt. They had advised their clients, criminal defendants, to ask former grand jurors about the factual basis of the indictment against them. Contempt liability hinged largely on the lawyers' knowledge that the grand jurors had taken a secrecy oath, id. at 396 (dictum). The oath itself made no reference to documents; the reference occurs in a quotation of the district court judge's charge to the jury. Id. at 395 . Apparently both the oath and charge were prescribed by the forum state's law-in this case, Ohio law. Id. See generally Orfield, supra note 5, at 360-62. There were no documents involved in the facts of the case, and the court did not comment on the described scope of secrecy. The convictions were reversed on grounds of judicial bias. $115 \mathrm{~F} .2 \mathrm{~d}$ at 398.

${ }^{24}$ See generally Orfield, supra note 5, at 402-13. 


\section{The Current Case Law on the Secrecy of Documents Subpoenaed By a Grand JuRy}

The federal courts have not provided any firm line of authority on the secrecy of documents subpoenaed by a grand jury as evidence. In the cases that have considered the issue, there has been substantial disagreement and little analysis. Factually, the cases fall into two groups. In the first group, specific documents are requested or the request is so descriptive that it could have been made, without a finding of oppression or overbreadth, directly to the owner of the documents had the grand jury investigation never begun. ${ }^{25}$ In the other group, the request is phrased in terms of grand jury possession or it is one that would have been denied had there been no grand jury proceeding. ${ }^{26}$

The leading case of the first type-involving the specific, narrowly drawn request-is United States $v$. Interstate Dress Carriers, Inc. ${ }^{27}$ The Interstate Commerce Commission had requested financial records of Interstate Dress Carriers that were in the possession of a grand jury investigating the firm. The Court of Appeals for the Second Circuit held that rule 6(e) was intended only to protect against disclosure of what was said or what took place in the grand jury room itself, and that documents are not protected unless they tend to reveal such matters. ${ }^{28}$ Thus, "when testimony or data is sought for its own sake-for its intrinsic value... -rather than to learn what took place before the grand jury, it is not a valid defense to disclosure . . . that the same documents had been, or were presently being, examined by a grand jury."29 Accordingly, the ICC was able to obtain the company's financial records without a showing of particularized need for them.

${ }^{25}$ United States v. Interstate Dress Carriers, Inc., 280 F.2d 52 (2d Cir. 1960); Capital Indem. Corp. v. First Minn. Constr. Co., 405 F. Supp. 929 (D. Mass. 1975); Davis v. Romney, 55 F.R.D. 337 (E.D. Pa. 1972); In re Hearings Before the Comm. on Banking \& Currency, 19 F.R.D. 410 (N.D. Ill. 1956); Michelin Tire Corp. v. United States, 453 F. Supp. 897 (Cust. Ct. 1978).

${ }^{28}$ In re Grand Jury Proceedings, 309 F.2d 440 (3d Cir. 1962); Cain v. United States, 239 F.2d 263 (7th Cir. 1956); In re Grand Jury, 469 F. Supp. 666 (M.D. Pa. 1978); In re Grand Jury Investigation of Ven-Fuel, 441 F. Supp. 1299 (M.D. Fla. 1977); United States v. Saks \& Co., 426 F. Supp. 812 (S.D.N.Y. 1976); Corona Constr. Co. v. Ampress Brick Co., 376 F. Supp. 598 (N.D. Ill. 1974); In re California, 195 F. Supp. 37 (E.D. Pa. 1961); United States v. Stein, 18 F.R.D. 17 (S.D.N.Y. 1955), rev'd on other grounds sub nom. United States v. Jackson, 257 F.2d 830 (2d Cir. 1958).

${ }^{27} 280$ F.2d 52 (2d Cir. 1960).

${ }^{28} \mathrm{Id}$. at 54.

${ }^{29}$ Id. (emphasis added). 
The analysis in Interstate Dress Carriers has been cited as controlling in several later cases, some of which are factually similar to Interstate Dress Carriers. In Davis v. Romney, ${ }^{30}$ for example, a federal district court held that the information contained in 23,000 file binders, which were before a grand jury investigating possible misconduct with regard to housing sold through FHA-insured mortgages, could not be denied to a civil plaintiff submitting interrogatories. ${ }^{31}$ The court pointed out that, just as in Interstate Dress Carriers, the information was requested not to learn what occurred before the grand jury, but rather for its own intrinsic value. It took special note of the fact that when the plaintiff first asked for the information contained in the binders, they were not yet before the grand jury. ${ }^{32}$

The intrinsic-value analysis has also been applied, however, in cases that are factually quite different from both Davis and Interstate Dress Carriers. In United States $v$. Saks \& Co., ${ }^{33}$ for example, the Federal Trade Commission applied for a court order permitting it to inspect and copy all documents obtained by the grand jury investigating alleged antitrust violations in the women's clothing industry. Unlike Interstate Dress Carriers or Davis, no attempt was made to ask for specific documents, or specific information, or even to define the requested documents in terms independent of grand jury possession so as to demonstrate that the agency did not wish to use the grand jury as its own investigative arm. ${ }^{34}$ Nevertheless, in granting the FTC's request, the court invoked the familiar distinction drawn in Interstate Dress Carriers between information sought for its own intrinsic value and that sought in order to discover what took place before the grand jury. ${ }^{35}$

The Saks court was correct in concluding that the FTC was interested in the documents for their own sake. That would be true, however, for all parties who might legitimately obtain docu-

${ }^{30} 55$ F.R.D. 337 (E.D. Pa. 1972).

s1 Id. at 340-41.

32 Id. at 341 .

s3 426 F. Supp. 812 (S.D.N.Y. 1976).

34 Id. at 813.

ss Id. at 814. In In re Investigation of Ven-Fuel, 441 F. Supp. 1299 (M.D. Fla. 1977), the Chairman of the Subcommittee on Oversight and Investigation of the House of Representatives' Committee on Interstate and Foreign Commerce requested and was granted documents presented to a federal grand jury in Jacksonville, Florida, except those relating to the criminal case that might be used as evidence at trial. Id. at 1302 . The court based its holding on two grounds: first, the reasoning of Interstate Dress Carriers, and second, the fact that the grand jury had finished its business. Id. at 1303. 
ments under the Interstate Dress Carriers standard. Many parties seek to obtain documents held by grand juries because of their intrinsic value, but nonetheless would be delighted to learn what had transpired before the grand jury. Knowledge of what has taken place in the grand jury proceedings might have a substantial bearing on a pending civil or regulatory case, or might lead the party to new and valuable evidence. Thus, the Interstate Dress Carriers test does not adequately limit disclosure.

Several courts have refused, however, to make any distinction between documents and transcripts of testimony in their analysis of the secrecy requirements of rule 6(e) ${ }^{36}$ In In re Grand Jury, ${ }^{37}$ the Commonwealth of Pennsylvania requested, for use in a trebledamage suit, all documents received as evidence by a grand jury investigating the anthracite coal industry. Holding rule 6(e) applicable, the court rejected the Interstate Dress Carriers test ${ }^{38}$ and stated that the institution of the grand jury might suffer if those submitting documents knew that their evidence might not be kept secret. Disclosure of documents is only available, the court held, after a showing of particularized need ${ }^{39}$ - the standard applied to transcripts of testimony.

The cases that have adopted the reasoning of In re Grand Jury have also involved broad requests for documents subpoenaed by a grand jury. These cases hold that "indirect" releases of grand jury information - the release of subpoenaed documents-however specific or limited, are no more permissible under rule 6(e) than "direct" releases of grand jury transcripts. ${ }^{40}$ In so holding, they avoid the difficult analysis of Interstate Dress Carriers. It is not necessary under this line of authority to determine whether documents are sought for their own intrinsic value or for their value in discovering what transpired in the grand jury room-a determination which, as has been demonstrated, fails to make a useful

${ }^{36}$ E.g., In re Grand Jury Proceedings, 309 F.2d 440, 443 (3d Cir. 1962); In re Grand Jury, 469 F. Supp. 666, 671 (M.D. Pa. 1978); Corona Constr. Co. v. Ampress Brick Co., 376 F. Supp. 598 (N.D. Ill. 1974); In re California, 195 F. Supp. 37, 40 (E.D. Pa. 1961); United States v. Stein, 18 F.R.D. 17, 19 (S.D.N.Y. 1955), rev'd on other grounds sub nom. United States v. Jackson, 257 F.2d 830 (2d Cir. 1958).

${ }^{37} 469$ F. Supp. 666 (M.D. Pa. 1978).

3s Id. at 671. The court dismissed the Interstate Dress Carriers analysis as not "the better view." Id. The court did not cite Interstate Dress Carriers. Instead it cited Illinois v. Sarbaugh, .552 F.2d 768 (7th Cir.), cert. denied, 434 U.S. 889 (1977), which in turn relied on Interstate Dress Carriers, id. at 772 n.2.

s9 469 F. Supp. at 671 .

to See cases cited note 36 supra. 
distinction.

The failure of these courts to make any distinction between documents and testimony creates a new problem, however, in that it forecloses any discovery of subpoenaed documents beyond that required by a particularized need. Requests for specific documents in grand jury files would be denied even though the requests were made before those documents became a part of the grand jury record, as in Davis $v$. Romney, unless particularized need could be shown. This result can be criticized in two respects. First, a potential litigant in a civil suit could shield documents from civil discovery by giving his only copies to the grand jury. Second, this result may unnecessarily constrict rule 34 of the Federal Rules of Civil Procedure, ${ }^{41}$ which provides for discovery of all relevant documents. The In re Grand Jury solution interprets rule 6(e) of the Federal Rules of Criminal Procedure as a modification of the civildiscovery standard when the grand jury holds the only copy of a document-and does so without considering whether it might be possible to design a solution that would satisfy the requirements of both rules.

Interstate Dress Carriers and In re Grand Jury, and their respective progeny, thus provide two different approaches for determining the applicability of rule 6(e) to documents held by a grand jury. Neither approach, however, is entirely adequate. Interstate Dress Carriers, although perhaps correctly decided on its facts, attempts to draw a distinction with no practical content. Any request for documents can pass its "intrinsic value" test, and the grand jury can thereby be turned into an investigative tool for the civil plaintiff. The holding of In re Grand Jury, although again quite defensible on its facts, would result in the denial of many requests for specific documents even though the documents would have been discoverable had there never been a grand jury investigation.

\section{The Proposed Solution: Channeling Discovery}

Prohibiting all civil discovery of documents held by a grand jury frustrates rule 34 of the Federal Rules of Civil Procedure. On the other hand, free discovery of documents held by the grand jury is likely to interfere with grand jury secrecy; analysis of the documents requested by the grand jury will often reveal many details

11 Fed. R. Crv. P. 34. 
concerning the investigation. It may be possible, however, to serve the policies of both rules by channeling all discovery requests through the original owner. If this proposal were adopted, all requests for documents would be made to their original owners and phrased in terms independent of any grand jury investigation. The document owner would then obtain the document from the grand jury and deliver it to the discovering party in the usual way, together with any other requested documents.

Admittedly, no rule of civil or criminal procedure describes this procedure. Nevertheless, the court with jurisdiction over the grand jury remains the guardian of the documents held by the grand jury and, as such, has the power to order the original owner to follow this procedure when he receives a discovery request..2 The court could, if necessary, enter such an order, conditioned upon a subsequent discovery request each time documents are submitted to the grand jury. Since no rule prohibits the suggested procedure, it could be employed without the formal entry of a conditional order every time documents are submitted.4s Indeed, the procedure has already been used by one district court, and noted without objection by an appellate court.44

This proposal is in accord with rule 34 of the Federal Rules of Civil Procedure. Documents held by a grand jury will still be discoverable, despite the existence of an ongoing investigation. Yet the fact that such an investigation is taking place will not aid the civil litigant: he will receive only those documents relevant under rule 34, and will not be able to use the grand jury as his investigative arm.

The proposal is also consistent with the text of rule 6(e). The grand jury's release of documents to their original owner is not a "disclosure" within the rule. The owner already is familiar with the contents of the documents, and he already knows that they are before the grand jury, so nothing is revealed by releasing the documents to him. Nor does the subsequent production of the documents for the discovering party create any problem under rule $6(\mathrm{e})$. Because rule $6(\mathrm{e})(2)$ only prevents grand jurors and govern-

12 Douglas Oil Co. v. Petrol Stops Northwest, 441 U.S. 211 (1979).

13 See id.

14 See Illinois v. Sarbaugh, 552 F.2d 768, 771-72 (7th Cir.) (dictum), cert. denied, 434 U.S. 889 (1977). (The district court's order is not reported.) Although the discovering party had already made the request to the court supervising the grand jury rather than through civil channels, the court ordered the documents returned to their owners in order to be available for civil discovery. 
ment personnel from disclosing privileged information, no violation would result from the document owner's response to the discovery. Indeed, extending the protection of rule 6(e) to documents might tend to reveal more information about the ongoing grand jury investigation than the proposed solution. If the discovering party is denied the information, he is alerted that there is an ongoing grand jury investigation and that the requested document is before the grand jury. If the procedure outlined here is adopted, the party seeking discovery often will learn neither that the grand jury holds a given document nor that a grand jury investigation is being conducted.

Nevertheless, the channeling approach is not required by the language of rule 6(e). Further, it is not clear from the language of the rule that "disclosure" should be interpreted so as to minimize interference with discovery in civil litigation. It is, therefore, necessary to consider whether the proposed solution is consistent with the purposes of rule $6(\mathrm{e}) .^{45}$

\section{The Purposes of Grand Jury Secrecy}

Although the legislative history of the rule does not reveal its purposes, the rule was a codification of the traditional practice of the courts. While the courts have not, until recently, addressed the issue of disclosure of grand jury documents, they have consistently held that the traditional practice of grand jury secrecy serves five purposes: (1) preventing flight of suspects; (2) preventing jury tampering; (3) preventing witness tampering and subornation of perjury; (4) encouraging persons with information to come forward; and (5) protecting the innocent. ${ }^{46}$ These purposes are served by the channeling approach-indeed, better served than by a scheme of absolute document protection.

45 Even when the material sought is clearly within the scope of the secrecy rule, courts often focus on the policy reasons for secrecy in deciding whether to allow disclosure. See, e.g., Douglas Oil Co. v. Petrol Stops Northwest, 441 U.S. 211, 223 (1979) (dictum); U.S. Indus., Inc. v. United States Dist. Court, 345 F.2d 18, 21 (9th Cir.), cert. denied, 382 U.S. 814 (1965).

18 E.g., Douglas Oil Co. v. Petrol Stops Northwest, 441 U.S. 211, 219 n.10 (1979); United States v. Amazon Indus. Chem. Corp., 55 F.2d 254, 261 (D. Md. 1931). See 1 C. WRIGHT, supra note $3, \S 106$, at 170 . In recent years, there has been considerable debate about whether these purposes continue to justify any form of secrecy. See, e.g., Calkins, Grand Jury Secrecy, 63 Mich. L. Rev. 455, 461-65 (1965); Dash, supra note 2, at 819-22; Knudsen, Pretrial Disclosure of Federal Grand Jury Testimony, 48 WASH. L. Rev. 423 (1973). 


\section{A. Preventing Flight}

Preventing the escape of persons under criminal investigation was probably the original reason for the practice of grand jury secrecy. ${ }^{47}$ Today, it is not a strong justification for the secrecy doctrine. Many persons under grand jury investigation are in jail or out on bail, and are aware that they are under scrutiny. ${ }^{48}$ Only when a grand jury is actually developing evidence, rather than being presented with evidence collected by the prosecutor, does grand jury secrecy prevent flight. ${ }^{49}$

Under the channeling approach, disclosure of documents will increase the chance of flight in only one situation. If the potential indictee knows he may be implicated in a current grand jury investigation and suspects that a particular individual possesses documentary evidence implicating him, he, or an associate, may bring a spurious civil suit against that individual in order to learn the contents of the documents. If the documents implicate him, he may flee. If the only copies of the documents were held by the grand jury and the suspect were denied discovery of the documents, he would be less likely to flee because he would not be certain whether the documents implicated him.

Although the proposed solution may increase the risk of flight in this situation, it should not be rejected for that reason. The increased risk arises in an improbable situation, and even there the risk is only marginally increased. If documents held by a grand jury were absolutely protected, the potential indictee might still have fled-either because the owner retained a copy of the documents and was therefore able to respond to the discovery request in the same way as under the proposed solution ${ }^{50}$ or because the suspicion that incriminating documents had been provided to the grand jury caused his flight.

Moreover, the incremental increase in risk of flight in this one at 426 .

17 See The Earl of Shaftesbury, 8 How. St. Tr. 759, 773 (1681); Knudsen, supra note 46,

48 See Dash, supra note 2, at 820. Moreover, those who have not been arrested could have been. If the prosecutor believes he has enough information to ask for an indictment, he almost certainly has probable cause sufficient to justify an arrest. Id. at 819 .

49 Dash recognizes that the argument for grand jury secrecy is stronger in the case of investigating grand juries. Id. at 822 . Moreover, those truly bent on escape can usually do so as well after indictment and arrest as during the grand jury's investigation; grand jury secrecy merely imposes the additional cost of jumping bail. Cf. FED. R. CRIM. P. 6(e)(4) (permitting sealed indictments).

so See note 8 supra. 
situation will be offset by a decrease in risk of flight in other situations. If documents are given absolute protection, the requesting party will learn both that a grand jury investigation is taking place and that the grand jury has seen the requested documents. Either of these pieces of information will increase the risk of flight. Thus, if the prevention of flight were the only justification for grand jury secrecy, a policy of allowing discovery through the original owner would appear preferable to absolute protection.

\section{B. Preventing Jury Tampering}

A second justification for grand jury secrecy is that it helps prevent potential indictees from attempting to intimidate, bribe, or importune the members of the grand jury. That purpose is unlikely to be frustrated by the proposed solution. Disclosure of subpoenaed documents does not, in itself, give the potential indictee any information about the identities or addresses of the jurors. The sole exception might be when the documents themselves somehow alert a potential indictee, who already has some independent knowledge of the investigation and of the identity of the grand jurors, that he may indeed be indicted-a situation unlikely to arise.

Furthermore, as with flight, absolute protection of documents will increase the likelihood of grand jury tampering in a variety of situations. If documents are given absolute protection, any document request will reveal both that there is a grand jury investigation and that the grand jury has seen the requested document. Either of these pieces of information may give a potential indictee his first suspicion that he may be indicted. It is therefore likely that the channeling approach will be more consistent with this purpose of grand jury secrecy than would absolute protection of documents.

\section{Preventing Witness Tampering and Subornation of Perjury}

Just as a potential indictee might attempt to sway the actions of grand jurors, he might importune, bribe, or threaten potential witnesses. Maintaining secrecy in grand jury proceedings helps avoid these dangers. The identity of witnesses is kept secret. Even if the potential indictee knows the identity of the witnesses, he usually will be unable to determine whether their testimony incriminated him.

Disclosure of documents in the possession of the grand jury does not in itself reveal the content of any witness's testimony 
before the grand jury. It is possible, however, that the existence of witnesses hitherto unknown to the potential indictee will be suggested by disclosed documents.

The channeling approach, however, will not on balance increase the likelihood of witness tampering or subornation of perjury. ${ }^{\text {b1 }}$ If documents are absolutely protected, the discovering party will learn that there is a grand jury and that it has the document. Witness tampering may thus result in cases in which, had the disclosure been made through the original owner without mention of any grand jury, there would have been no witness tampering. Moreover, the channeling approach will not increase the risk of witness tampering in those instances in which the original owner retained a copy of the document.

\section{Encouraging Persons with Information to Come Forward}

Persons having information about criminal activity may be reluctant to reveal it, either by testifying before a grand jury or by turning over documents. They may fear retribution from the persons they implicate, or they may be concerned that the information they reveal will expose them to civil liability. ${ }^{52}$ The secrecy rule encourages such persons to bring their evidence forward voluntarily, or to respond more frankly and completely to subpoenas..$^{\text {s }}$

In the context of document disclosure, this reason for secrecy raises two separate issues. If the owner of documents is fearful of retribution, then document disclosure should be made, if at all,

s1 The proposed solution avoids the great danger that would arise were documents freely discoverable. Potential indictees would then have a means to check up on the effectiveness of threats or bribes; obtaining the documents from the grand jury reveals exactly what was given to the grand jury. Under the proposed procedure, the owner will have control over the documents given the discovering party. Discovery need not reveal that the original owner is complying with the grand jury's requests.

${ }^{82}$ For most potential witnesses, of course, an even greater reason for reluctance is the fear of subjecting themselves to criminal liability. Cf. U.S. ConST. amend. V (privilege against self-incrimination). Although this is undoubtedly a central factor in grand jury proceedings, it has no bearing on the secrecy rule; the very parties from whom the potential witness most wants to hide his information-the government and the grand jury-are not hindered by this rule.

${ }^{\text {ss }}$ Grand jury secrecy may not give the potential witness protection when his fear is that he will have to testify at a public trial. That does not, however, render secrecy valueless. Prosecutors may often be able to promise a grand jury witness that he will not be called at trial. For example, the prosecutor may be confident of conviction by plea bargaining, or may plan to induce one indictee to turn state's evidence. Moreover, there may be cases in which the witness fears that the person he accuses will emerge unindicted. 
only in such a way as to avoid revealing what information the grand jury has and from whom it got it. If the owner fears that facts contained in the documents might lead to his own civil liability, then the important consideration is that a party requesting documents from the grand jury should not obtain more material than he could have obtained had there been no grand jury. Both of these considerations are satisfied by requiring that all requests for documents be channeled through the original possessor and be phrased in terms independent of grand jury possession.

\section{E. Protecting the Innocent}

Grand jury secrecy protects the reputations of persons called to testify, or otherwise implicated in a grand jury investigation, but ultimately absolved of any indictable offense. ${ }^{54}$ Disclosure of documents can damage the reputation of an innocent person in two ways. First, the contents of the documents, rather than the fact that they are held by the grand jury, may cause unjustified suspicions. In this situation, the harmfulness of the document has nothing to do with the existence of a grand jury. Whether such a document can be discovered should not, therefore, turn on whether the document is in the possession of a grand jury. Moreover, the disclosure encouraged by the channeling approach is unlikely to increase significantly the likelihood of injury to reputation. Disclosure is not made to the public at large, but to a particular discovering party-typically a civil plaintiff or a government agency. The harmful material is likely to reach only a small audience. Indeed, there is little reason to withhold the information from this audience. A person absolved of criminality does not have the right to shield his acts from appropriate civil remedies.

The disclosure that a grand jury is examining particular documents may also injure the reputation of the innocent by giving rise to unfounded suspicions. This danger is enhanced by denying discovery of such documents. The denial of the discovery request will inform others that a grand jury is examining the particular documents. Yet the contents of the documents will remain secret, thus creating suspicions. By contrast, disclosure under the channeling approach reveals only the contents of the documents and not the

s4 At congressional hearings conducted in 1977 , the need to protect reputations was cited as a reason for grand jury secrecy. See Grand Jury Reform: Hearings on H.R. 94 Before the Subcomm. on Immigration, Citizenship, \& International Law of the House Comm. on the Judiciary, 95th Cong., 1st Sess. (1977). 
fact that a grand jury is examining them.

\section{ConClusion}

Rule 6(e) and its legislative history do not clearly indicate whether documents held by a grand jury are within the scope of the rule. The courts have taken two different approaches: permitting the disclosure of documents sought for their intrinsic value or treating all such document requests as comprehended by rule 6(e). The former approach ignores the need for secrecy concerning the grand jury investigation. The latter permits the possession of the document by the grand jury to act as a nearly absolute bar to civil discovery.

This comment proposes that document requests be channeled through the original owner. The owner will obtain a copy of the requested documents from the grand jury and provide them to the requesting party. The major risks attending the channeling approach are precisely those that would occur were the owner to retain copies of the requested documents. Yet the approach will balance properly the interests of grand jury secrecy. It will permit civil discovery of documents held by a grand jury, while remaining faithful to rule 6(e) and the purposes of grand jury secrecy.

Gail Heriot 